\title{
MEASURING SMES' SUSTAINABILITY: A LITERATURE REVIEW AND AGENDA FOR RESEARCH
}

\author{
Bulan Prabawani ${ }^{1}$ \\ ${ }^{\text {IS }}$ chool of Business Administration, Diponegoro University, Indonesia
}

\begin{abstract}
Environmental hazards can be caused by firms' lack of awareness of social and natural concerns. Firms of all sizes can have significant environmental impacts at regional and global levels. Small and medium-sized enterprises (SMEs) form the majority of all businesses in developing and developed economies, contribute to national GDP and make significant distributions to employment, but they have fundamental problems in terms of resources and this tends to harm their business sustainability. Various methods to review business sustainability have been developed. However, researchers have not yet assessed SMEs' sustainability levels using comprehensive measures. This is particularly problematic in the manufacturing sector because the purpose of this review of SMEs' sustainability is the criteria that can be used to assess SMEs' sustainability levels. These criteria include firms' internal and external factors and stakeholders as well as present and future interests. As such this paper establishes a basis for future research.
\end{abstract}

Keywords: SMEs, Sustainability, Measurements, Level.

Received: 24 October 2013/ Revised: 29 October 2013/ Accepted: 1 November 2013/ Published: 8 November 2013

\section{INTRODUCTION}

Sustainability is not a new concept. It has been overused and sometimes even misused by many scholars. Sustainability has been taken to refer simply to continuous ability. For instance, business sustainability is applied to longstanding firms' resistance towards external shocks. This usage is not entirely false. However, sustainability has wider scope, and is not limited to business management. It also considers present as well as future interests.

Sustainability was initially introduced by the Brundtland Commission in 1987 as a global concern about environmental damage. The Millennium Ecosystem Assessment (MA) in 2005, which was funded by the United Nations (UN), World Bank, and Global Environment Facility, indicated that ecosystem damage had resulted in a massive wave of species extinction, threatening lives and well-being. According to The World Conservation Union and Species Survival 
Commission (2004), human activities in the past 500 years have caused the extinction of 844 species. It is due to habitat destruction, over-exploitation, pollution, disease, invasion of aliens' species, and global climate change (Schipper et al., 2008; Schipper et al., 2008). "A total of 15,589 species of plants and animals are known to face a high risk of extinction in the near future, in almost all cases as a result of human activities. This includes $32 \%$ of amphibian species, $24 \%$ of mammal species, $12 \%$ of bird species, $25 \%$ of conifers and $52 \%$ of cycads (an ancient group of plants)" (The World Conservation Union and Species Survival Commission, 2004). Furthermore, the world's atmospheric $\mathrm{CO}_{2}$ levels have risen 20ppm over the last 8000 years (Broecker et al., 2001). $\mathrm{CO}_{2}$ is important for plants and animals such as for photosynthesize and respiration. It is useful for various industries. For example to create soft drinks and baking soda, air conditioning, and fogging effect in theatres, but at a certain level it can lower oxygen concentration, which is dangerous for human health. It may cause asphyxiation, frostbite, and kidney damage or coma. (MD et al., 2009). These environmental changes, if left unresolved, will harm firms through resource scarcity. Resource scarcity and higher population density will increase material prices due to high demand and limited supply, and consequently firms will need to reduce costs. For example, firms might start to down grade employees' welfare by offering lower benefits and health insurance, which, in turn, would impact on the safety of consumer products, communities' interest in prosperous living, and business transparency and accountability.

It is indisputable that all firms affect the social and natural environments (Will, 2008). Individual SMEs may have little environmental impact, but cumulatively they have a considerable impact, not only on the economy, but also on the social and natural environment (Lawrence et al., 2006). SMEs employ $45 \%$ of the workforce in the UK, $66 \%$ in the EU (Castka et al., 2004), $72 \%$ in Japan (LEDIS, 2007) and 97\% in Indonesia (ICBS, 2008). In Australia, small firms provide 46\% of private sector employment (The World Conservation Union and Species Survival Commission, 2004). In addition, SMEs have been found to be more dynamic than larger enterprises, which has contributed to their resilience to external shocks (Castka et al., 2004; Adiningsih et al., 2006; LEDIS, 2007) and their ability to show increased growth. Globally, SMEs account for an average of $50 \%$ of GDP, $30 \%$ of the total volume of exports, and $10 \%$ of foreign direct investment (FDI) value (Hall, 2003).

However, SMEs generally have limited resources and capabilities. Many SMEs are at risk, have limited warranty, and lack business experience or a track record, which means creditors hesitate over giving them credit (Borga et al., 2009; Rammer et al., 2009). In addition, SMEs also gain little public attention from the media (Masurel, 2007; Werbach, 2009), community and government (Belu, 2009). Consequently, SMEs tend to be indifferent to implementing environmentally friendly practices, which commonly require more capital and public scrutiny. Moreover, according to Masurel (2007), SMEs tend to act as if nature is able to regenerate itself quickly and is able to withstand various kinds of waste generated by industry. Furthermore, SMEs' key persons (owners or managers) often believe that their firm does not have a significant impact on the natural and social environment (Lawrence et al., 2006; Masurel, 2007). Thus, for 
SMEs, the natural environment frequently becomes the object of exploitation and does not receive adequate attention for regeneration (Masurel, 2007). In other words, SMEs have low sustainability awareness.

Some studies have analyzed firms' sustainability applications, both in larger and smaller firms, but no research has used a comprehensive measure of sustainability. Fortunately, various methods and criteria have been developed to review firms' sustainability. For examples, Borga et al. (2009) have constructed detailed criteria for sustainability in SMEs, and Belu (2009) has ranked industrial sustainability practices. In addition, Lawrence et al. (2006) focused on sustainability applications in SMEs in New Zealand settings. The purpose of this paper is to provide basic and comprehensive criteria to measure SMEs' sustainability levels.

This paper has four sections: in the first the sustainability concept and its basic elements is explained; in the second detailed criteria to measure SMEs' sustainability are reviewed; in the third levels of sustainability allowing for categorization of business sustainability are given; and in the fourth a agenda is established to close the gaps in the literature.

\section{SUSTAINABILITY: DEFINITION AND CONCEPT}

The report of the Brundtland Commission in 1987, which was established by the World Commission on Economic Development (WCED), defined the sustainable development concept as "meeting the needs of the present without compromising the ability of future generations to meet their own needs" (Brundtlant Commission, 1987). The concept is based on two fundamental conditions: the existence of human needs, and limited resources. This means that to achieve balance, human needs should be given priority; furthermore, the limitations in resources must be accommodated by technology and social activity to meet the needs of the present and the future (Brundtlant Commission, 1987).

In the business sector, sustainable development is translated into something that "meets the needs of its stakeholders without compromising its ability to meet their needs in their future" (Hubbard, 2009). Likewise, Savitz and Weber (2006) states that a sustainable firm is "one that creates profit for its shareholders while protecting the environment and improving the lives of those with whom it interacts". Thus, sustainability emphasizes the balancing of stakeholders' needs and profits with protecting the environment.

Meeting the everyday needs of humans and business entities must be in harmony with their natural and social environments. Nature provides a variety of resources for food, drink, shelter, health, and, in industry, to create new products for human needs. Thus, in order to sustain resources, no more should be taken out than that can be naturally, or non-naturally, replaced. Whereas, firms act as suppliers of goods and services to obtain profit; society provides labor to obtain salary and wages, customers consume products and services to live; and investors give credit to achieve a rate of return. A mutual relationship between the environment and business is 
required as there is a clear intersection between business, the natural environment, and social interest.

Sustainable development concept has been adopted by business in terms of "sustainability" on a general and global level (Werbach, 2009). However, the application of sustainable practices is often inappropriately equated to corporate social responsibility (CSR), responsible business, or corporate social performance (CSP) by organizations and academia. For example, the UK authorities, through their www.csr.gov.uk website, mention "There are many definitions but we are all talking about how business takes account of its economic, social and environmental impacts in the way it operates maximizing the benefits and minimizing the downsides." (Tang, 2009). Here, CSR is equalized with sustainability, which consists of three pillars: economic, social, and environmental. However, according to Savitz and Weber (2006), there is a difference between CSR and sustainability. CSR stresses the importance of social groups outside the enterprises, whereas sustainability places enterprises' interest as equal to the interest of society and nature. Similarly, Borga et al. (2009) mention that CSR has too much focus on the social aspect; furthermore, it is a "big business framework", which requires considerable financial resources to be implemented. Therefore, CSR has the potential to be a discontinued program because it depends on firms' financial performance. Moreover, it is commonly taken to be no more than charity (Godfrey et al., 2009).

The interaction of firms with the natural and social environment is popularly referred to as triple bottom line (TBL) (Elkington, 1994; Savitz and Weber, 2006). The concept has been used by some researchers (Hart and Milstein, 2003; Borga et al., 2009; Hubbard, 2009) to appraise firms' sustainability. According to Elkington (1994), firms' investors, governments, suppliers, trade associations, employees, communities, customers, and political groups' needs should be in balance with the interest of shareholders.

The TBL reveals that the key measurements of the economic dimension of TBL focus on firms' welfare. The natural dimension emphasizes resource consumption and waste, while the social dimension focuses on the impact a firm has on the people with whom the firm interacts, such as employees, communities and customers. Accordingly, while past firm performance is often judged purely by economic value, assessment of current firm success and sustainability must address the natural and social aspects as well as the economic aspects (Hubbard, 2009).

\section{MEASUREMENTS OF SMES' SUSTAINABILITY}

As outlined above, natural, social and economic dimensions are usually expanded into more detailed elements (Hart and Milstein, 2003; Lawrence et al., 2006; Borga et al., 2009; Hubbard, 2009). However, elements have been modified to measure firms' sustainability in certain settings. Hart and Milstein (2003) created a brief sustainable value framework for business (see Figure 1). This framework takes into account firms' internal and external issues, as well as their present and future interests. The internal and present-day interests of firms include pollution, consumption and waste, which require pollution prevention. The internal and future interests require clean 
technology due to the fact that minimizing environmental disruption entails a reduction of the human footprint on the planet. The external and present-day interests focus more on civil society and stakeholders' demands for transparency and connectivity; the latter require a product stewardship strategy by integrating the stakeholders' view into the business process. The external and future interests are associated with the problem of increasing world population, poverty and inequity, which require firms to have a sustainability vision. Thus, Savitz and Weber (2006) state that to initially develop a sustainability program, firms should not place sustainability approaches as parallel programs; but they should be part of an integrated program in which the value framework is a useful tool to acknowledge a firm's strategy and the issues forcing sustainability.

Figure-1. Sustainable Value Framework

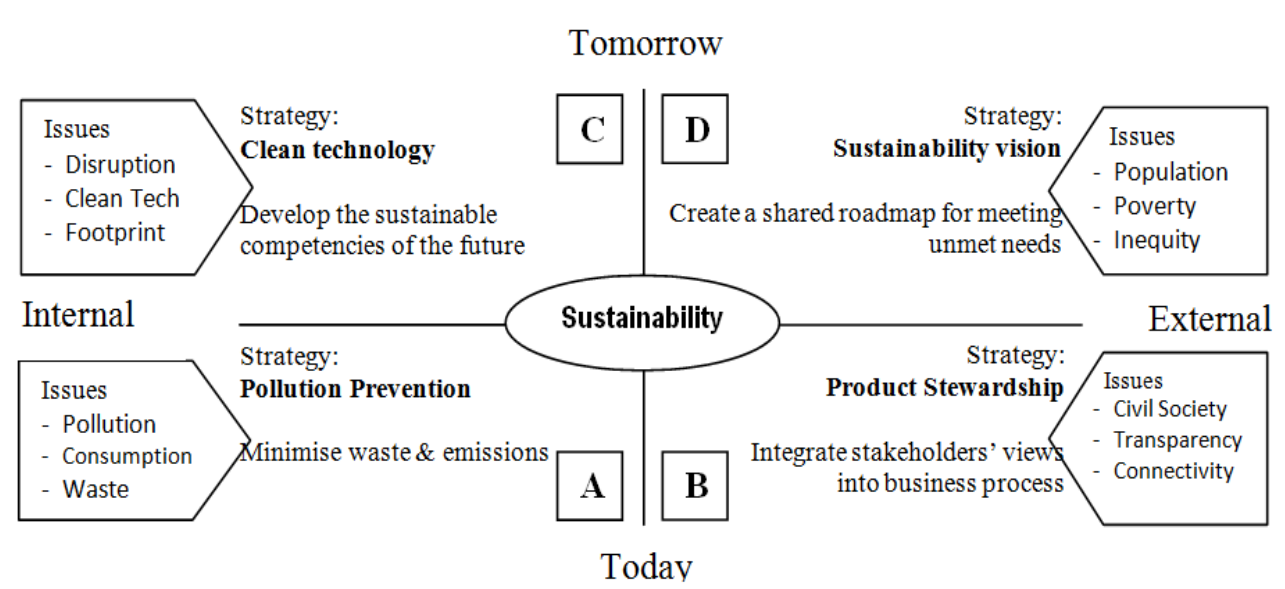

Source: Hart and Milstein (2003)

To implement sustainability, firms should have an appropriate business strategy. Firms should make adjustments, not limited to their investments in operational cost alone, but also in the form of policy and even in vision and mission changes, because business operations need not only financial resources, but also social and natural resources (Savitz and Weber, 2006), because sustainability in business terms is more than how to run "green" businesses, or to simply focus on the natural environment, but also how the business strategy is implemented by taking into account the firms economic and social sustainability (Werbach, 2009). As examples, the Toyota Motor company quickly gained profit using a sustainability strategy by producing quality, fuelefficient small cars (Werbach, 2009) and hybrid power system vehicles (Hart and Milstein, 2003). Ford Motor Company, in stark contrast, pursued a different "large-vehicle" strategy which has failed, resulting in losses throughout 2007 and 2008. Werbach (2009) evaluates the different results of the two enterprises judging that Toyota has successfully incorporated four sustainability aspects (economic, social, natural and cultural), by understanding the changes that 
society demands regarding community and the natural environment and has been able to adjust its management culture.

In looking at sustainability, a research of Lawrence et al. (2006) on 811 New Zealand SMEs, comparing sustainability practices between small, medium and large-sized enterprises. They included natural environmental practices related to policy statements, programs, management systems and reporting, recycling programs and waste and resource management. The social concerns were facilitating employee training and education, flexi-time, stress management, community projects, and charity work. They found that, although SMEs had relatively fair social concerns particularly towards the employees and the communities, most did not have formal environmentally-friendly reports.

In another study, Borga et al. (2009) developed sustainability reporting guidelines for SMEs, which they claimed were "simpler and clearer" than Global Reporting Initiatives (GRI) and Company Environmental Reports (CERs) that are commonly adopted by big business such as Coca Cola. Borga et al. (2009) also contended that a lack of sustainability reporting guidelines was one of the main barriers for SMEs applying sustainability. The guidelines represent essential interaction and communication mediums for SMEs and were formulated from literature and case studies on Italian SMEs. The result was a detailed reporting on elements of company identity, economic impact, social impact, and natural environmental impact. Economic impact covered economic performance indicators, such as shareholders' equity and profit/loss. Social impact contained indicators identifying relationships between business and employees, customers, suppliers, local communities, public authorities, and other stakeholders; whereas natural impact identified environmental policy, raw material, energy, water consumption, air emission and noise level, waste management, and environmental impact of products. However, the studies of Borga et al. (2009) and Lawrence et al. (2006) did not sufficiently explore the theories underlying the item guidelines developed by Hart and Milstein (2003). In addition, neither mentioned operational measurements towards the commitment of future interest such as the use of renewable raw material and/or energy.

Hubbard (2009) adopted the sustainable value framework of Hart and Milstein (2003) and extended it with ideas from the balance scorecard and stakeholders theory to construct a sustainable balanced scorecard framework and organizational performance index. He included as the elements: customers, social performance, natural environmental performance, finance, internal process, and learning and development performance. He applied several important economic issues to the social element; for example, he chose market share, the number of new customers, and the order cycle time as social dimensions to sustainability, rather than customer satisfaction, level of customers' involvement, and privacy protection of customers' data. But, he applied a single measure for each element. For instance, employee satisfaction was the only criteria to measure employees fulfillment, which has potential to be split into several measurements, such as employee benefits, training, labor turnover, and equality of treatment, as proposed by Borga et al. (2009) and Lawrence et al. (2006). 
While Borga et al. (2009) and Lawrence et al. (2006) offered a comprehensive measurement; they did not provide the measurements of future interest. They only focused on firms' current concerns, so that renewable energy and raw material perspectives were not considered. In addition, the external parties were limited to those which had a direct relationship with firms; they did not regard poor communities and/or radical environmentalists as stakeholders as according to Hart and Milstein (2003) a poor community has significant potential benefits for growth trajectory. They refer to the success of the Grameen Bank in Bangladesh, which provides microcredit for the poorest people, and Unilever, which develops a market for the rural poor in India. These initiatives are included in firms' external and future concerns, whereas the internal and beyond interests represent the importance of clean technology strategy.

Using the indicators to measure firms' sustainability that have been developed from the previous studies, of Hart and Milstein (2003), Lawrence et al. (2006), Borga et al. (2009), and Hubbard (2009), a comprehensive set of indicator to measure sustainability are outlined in Table-1.

Table-1. Natural and Social Measurements to SMEs' Sustainability

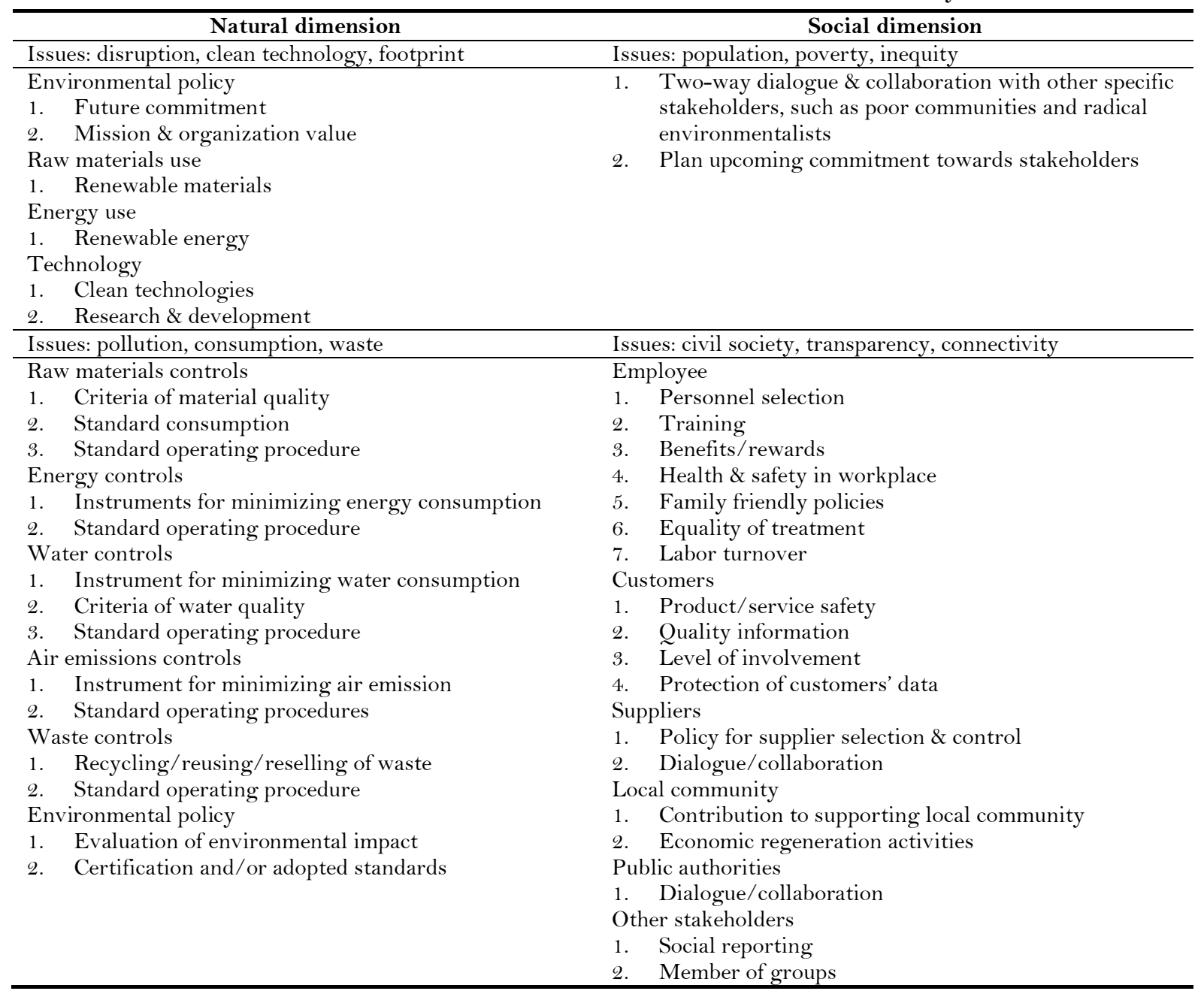


The economic dimension of sustainability is reviewed variously by academics. It can be an independent variable (input), or a dependent variable (output). For examples, Belu (2009) regards ROA (return on asset), ROI (return on investment) and ASR (average stock return) as economic inputs to sustainability. Thereafter, he analyses how economic dimensions influence a firm's sustainability. If a positive correlation exists, he concludes that financial performance encourages sustainability practices. By contrast, Rao et al. (2009) consider economic performance to be the output of environmental performance and management in certain Philippine SMEs because the SMEs want to provide evidence that environmental performance can "lead to superior business performance and competitiveness". Several other experts (Borga et al., 2009; Hubbard, 2009) unite economic performance with social and natural performance to form a balanced score card, stressing on sales and profit. Hubbard (2009) and Rao et al. (2009) add the indicators with research and development spend, order cycle time, market share, and productivity.

However, many SMEs do not use financial information, such as ROI and ROE, but their sustainability practices may depend on their financial performance. It is therefore necessary to make the economic dimension an input or independent variable because SMEs' operational decision making is often dependent on the financial performance. Moreover, the economic dimension should not simply be represented in numerical terms (quantitative), but should be based on the perception of key persons (qualitative). The simple indicators are the ones that are clearer for SMEs' key persons, who do not have sufficient data or even recognize the concepts of used by Belu (2009), Hubbard (2009) and Rao et al. (2009), return on equity (ROE), return on sales (ROS), ROA, ROI, efficiency and cost saving. SMEs will be able to comprehend their growth of sales, cost reduction and jobs created.

\section{LEVEL OF SMEs' SUSTAINABILITY}

According to Savitz and Weber (2006), there is an indicating tendency for firms to implement sustainability practices using TBL measurements as indicators of their success, and report these to their economic, natural and social stakeholders. Similarly, stakeholders also use TBL key measurements to evaluate firms. Will (2008) adds that there is a shift in vision of business sustainability from merely a business vision to that of a social vision, where sustainability goes beyond legal requirements. However, Belu (2009) evaluated 1,012 companies listed on the world stock markets to reveal many demonstrated low sustainability performance. Even the financial sector had lower levels of sustainability than the primary industry. According to Belu (2009), this was because banks, insurance companies and other firms in the financial sector had already achieved very good financial performance levels, and therefore tended to neglect sustainability issues.

SMEs' reluctance to implement sustainability is possibly because, as studies show, sustainability seems not to significantly affect the firm's financial performance. For example, research by Scholtens (2006) reveals that financial performances has a weak relationship with firms' sustainability. Other studies show that financial performance and sustainability has a 
negative relationship. This means that when firms in the service sector increase their sustainability, financial performance declines. This might be caused by the service sector not using inputs and outputs that significantly affect natural and social life, or, they may have little public attention so there is less pressure from stakeholders (Belu, 2009; Werbach, 2009). Either way, sustainability is likely to be abandoned. Moreover, many firms that claim to have properly implemented sustainability, only carry out charity programs to poor communities or practice waste treatment management, or use renewable natural resources. However, as Savitz and Weber (2006) firmly state, "sustainability is not about philanthropy. There is nothing wrong with corporate charity, but the sustainable firm conducts its business so that benefits flow naturally to all stakeholders".

Borga et al. (2009) claim that although large firms with big capital are reluctant to implement sustainability, the level of sustainability in SMEs is even lower because SMEs commonly lack resources, access, and business record (Borga et al., 2009; Rammer et al., 2009). In addition, as Masurel (2007) note, SMEs receive less public, government, community, and media attention which make them less aware of environmental issues.

Some researchers have developed methods to measure firms' level of sustainability. Hubbard (2009), who applies sustainable balanced scorecard and organizational sustainable performance index, combines sustainability elements with organizational performance index. The sustainability elements are rated by comparing performance of present and previous periods with a simple scale of 1 (bad) to 5 (good). However, the study of Hubbard (2009) mostly uses empirical and numerical data that are not "readily available" particularly in SMEs. Moreover, the study only presents the growth of each element, but is unable to explain the meaning of each rating, which means that the approach does not provide much description of the firms' sustainability practices.

Table-2. Level of human and ecological sustainability

\begin{tabular}{|c|c|c|}
\hline Phase & $\begin{array}{c}\text { Human sustainability } \\
\text { (Social dimension) }\end{array}$ & $\begin{array}{c}\text { Ecological sustainability } \\
(\text { Natural dimension })\end{array}$ \\
\hline $\begin{array}{l}\text { One: } \\
\text { Rejection }\end{array}$ & $\begin{array}{l}\text { Employees and subcontractors exploited. } \\
\text { Community concerns are rejected outright. }\end{array}$ & $\begin{array}{l}\text { The natural environment is regarded as a free } \\
\text { good to be exploited. }\end{array}$ \\
\hline $\begin{array}{l}\text { Two: } \\
\text { Non-Responsiveness }\end{array}$ & $\begin{array}{l}\text { Financial and technological factors exclude broader } \\
\text { social concerns. }\end{array}$ & $\begin{array}{l}\text { Ecological factors are excluded from decision- } \\
\text { making. }\end{array}$ \\
\hline $\begin{array}{l}\text { Three: } \\
\text { Compliance }\end{array}$ & $\begin{array}{l}\text { The emphasis is on compliance with legal } \\
\text { requirement in industrial relations and safety. }\end{array}$ & $\begin{array}{l}\text { Ecological issues unlikely to attract strong } \\
\text { litigation or strong community action are ignored. }\end{array}$ \\
\hline $\begin{array}{l}\text { Four: } \\
\text { Efficiency }\end{array}$ & $\begin{array}{l}\text { Community projects and HR value-adding } \\
\text { strategies are pursued only when a cost benefit to } \\
\text { the company is obvious. }\end{array}$ & $\begin{array}{l}\text { Natural environmental issues are ignored if they } \\
\text { are not seen as generating avoidable costs or } \\
\text { increasing inefficiencies. Sales of by products are } \\
\text { encouraged. }\end{array}$ \\
\hline $\begin{array}{l}\text { Five: } \\
\text { Strategic Pro-activity }\end{array}$ & $\begin{array}{l}\text { Intellectual and social capital is used to develop } \\
\text { strategic advantage through innovation in } \\
\text { products/services. }\end{array}$ & $\begin{array}{l}\text { Proactive natural environmental strategies such as } \\
\text { product and process redesign are seen as source of } \\
\text { competitive advantage. }\end{array}$ \\
\hline $\begin{array}{l}\text { Six: } \\
\text { The Sustainability } \\
\text { Enterprise }\end{array}$ & $\begin{array}{l}\text { Key goals both inside and outside the firm are the } \\
\text { pursuit of equity and human welfare and potential. }\end{array}$ & $\begin{array}{l}\text { The firm works with society towards ecological } \\
\text { renewal and positive sustainability policies. }\end{array}$ \\
\hline
\end{tabular}

Source: Benn et al. (2007) 
Similarly, Lawrence et al. (2006) analyze firms' sustainability by comparing the practices over small, medium, and large enterprises. However, they do not provide detailed information of firms' sustainability practices. A more promising approach is taken by Benn et al. (2007), who present criteria of human and ecological sustainability to describe firms' level of sustainability. According to Benn et al. (2007), the implementation of firms' sustainability can be viewed from two perspectives namely "human sustainability", which gives an overview of development and fulfillment of human needs, and "ecological sustainability", which provides protection and renewal of the biosphere. These provide a description of the firms' sustainability performance, and also the process of change towards sustainability practices, as shown in Table 2.

Human sustainability, as a social dimension, shows human behavior in a business entity as one which uses resources and deals with external demand. Ecological sustainability, as a natural dimension, emphasizes human behavior in a business entity as viewing and impacting on the natural environment through the firm's strategy and decision making. However, the approach needs several adjustments since the elements are not constant. For example, it determines employees, subcontractors, and community as the elements of rejection phase of social dimension, but these are unavailable in stage two, which is non-responsiveness. Thus, the phases are amended to be the following:

1. Rejection is that the firm places natural and social interest as objects of exploitation.

2. Non responsiveness is that the firms do not regard social and natural environment as objects of exploitation. However the firm excludes the social and natural concern from the decision making process.

3. Compliance is that the firm pays attention to the natural and social environment for the purpose of legal compliance.

4. Efficiency is that the firm generating environmental issues if only the cost benefit is obvious.

5. Strategy pro activity is that the firm actively develops innovation for the purpose of competitive advantages.

6. The sustainability firm is that the firm cooperate with social and natural interests for the purpose of the firm's and human welfare and natural renewal

There are several alternatives to determine the level of SMEs' sustainability by applying qualitative or quantitative measures, or a combination of both. In qualitative research, a researcher conducts a case study, focus-group discussion, or an in-depth interview to analyze the level in firms' sustainability. However, qualitative study is not applicable if a study would like to generalize-ability which is provided by the quantitative one.

In a quantitative methodology such as a survey, each measurement can be directly classified into the modification of the sustainability level of Benn et al. (2007). Then, non-parametric statistics can be applied to determine SMEs' sustainability level. However, it is time consuming, since respondents should grade each measurement into a single level, which requires critical consideration. 
Another quantitative technique is using a Likert scale or any other interval scale. It is easier for respondents since they only have to assess each sustainability item without classifying their classes. Respondents should only state their level of agreement or disagreement towards items in the questionnaire. Similarly, it will be difficult to conclude which level is their level, since it may result in a decimal value, which makes it difficult to the level of the firm's sustainability. For example, if social dimension to sustainability results in 3.5, this value is between the level of compliance (stage three) and efficiency (stage four). Moreover, it is not appropriate to mention that a 1 to 6 interval scale is the same level as the sustainability level for rejection (the first or lowest level) to the sustainability enterprises (the sixth or highest level).

Thus, if applicable, a researcher may apply mixed methods since quantitative method provides generalize-ability, while the qualitative one offers deeper explanation and information.

\section{CONCLUSION}

This literature review reveals several gaps relating to the measurement, the methodology, and the current results of a firm's sustainability. Firstly, several researchers, such as Lawrence $e t$ al. (2006), Belu (2009) and Rao et al. (2009), have provided sustainability indicators to measure a firm's sustainability,. However, most do not discuss the firm's sustainability level, which as formulated by Benn et al. (2007), consists of 6 (six) levels: rejection, non-responsiveness, compliance, efficiency, strategic pro-activity and the sustainability enterprises.

Secondly, Benn et al. (2007) do not reveal how to measure a firm's economic dimension, which is a basic part of the Elkington's triple bottom line (TBL) (Savitz and Weber, 2006). Consequently, it is necessary to combine measurements of several economic dimensions, such as those developed by Belu (2009), Rao et al. (2009) and Hubbard (2009).

These measurements are: return on asset (ROA), return on investment (ROI), return on equity (ROE), average stock return (ASR), and efficiency and cost saving. However, SMEs may have difficulty providing these data.

Thirdly, Hubbard (2009) gives an idea of how to measure a firm's sustainability using a balanced scorecard, which has already become a common concept. But, he did not consider the external parties and issues beyond the present time, which are important elements of sustainability. Thus it is essential to adopt the approach of Hart and Milstein (2003) who consider the internal and external parties, as well as present and future issues.

Fourthly, many studies have provided sustainability measurements, but they have discussed these from different and partial points of view. As examples: Benn et al. (2007) only discuss the social and natural dimensions to sustainability and do not focus on SMEs; Hubbard (2009) focuses more on economic dimensions but only as applicable to large enterprises; and Rao et al. (2009) assess the relationships between dimensions.

Therefore, it is important for SMEs to integrate these studies. Additionally, the research of Borga et al. (2009) and Lawrence et al. (2006) are also useful as they provide comprehensive sustainability measurements for SMEs, particularly in the manufacturing industry. 
Therefore, the contribution of this study is to provide comprehensive criteria to assess SMEs' sustainability level based on a review of the literature. The indicators to measure sustainability have been developed from several relevant studies.

The first is the sustainable value framework of Hart and Milstein (2003), which gives fundamental issues and strategies to measure sustainability. The second is the sustainable balance scorecard of Hubbard (2009), which measures a firm's sustainability by sustainable balance scorecard. Both these approaches are enriched with the measurements of Borga et al. (2009), which supplies the indicators of reporting guidelines for small enterprises and the natural and social practices to SMEs' sustainability of Lawrence et al. (2006).

Finally, further research could undertake the sustainability level of Benn et al. (2007) with several modifications to asses firms' sustainability level, and set economic dimension to sustainability as the input or factor influencing the firms' sustainability level.

\section{Funding: This study received no specific financial support.}

Competing Interests: The author declares that there are no conflicts of interests regarding the publication of this paper.

Contributors/Acknowledgement: The author would like to acknowledge that this paper is part of the author's PhD thesis in Edith Cowan University, WA, with financial support from Directorate General of Higher Education, Indonesia. Also, valuable guidance from different insight of Professor Rowena Barrett (ECU) is appreciatively acknowledged with all remaining errors are entirely mine.

\section{REFERENCES}

Adiningsih, S., A.I. Rahutami, R.P. Anwar, R.S. Wijaya and E.M. Wardani, 2006. A decade of post indonesian crisis (satu dekade pasca krisis indonesia). Yogyakarta - Indonesia: Penerbit Kanisius.

Belu, C., 2009. Ranking corporations based on sustainable and socially responsible practices. A data envelopment analysis (DEA) approach. Sustainable Development, 17(4): 257-268. Available from http://Oproquest.umi.com.library.ecu.edu.au/pqdweb?did=179312982 $1 \& \mathrm{Fmt}=7 \&$ clientI $\underline{\mathrm{d}=7582 \& \mathrm{RQT}=309 \& \mathrm{VName}=\mathrm{PQD}}[$ Accessed 27 April 2010].

Benn, S., D. Dunphy and A. Griffiths, 2007. Enabling change for corporate sustainability: An integrated perspective. Australasian Journal of Environmental Management, 13(3): 156-165.

Borga, F., A. Citterio, G. Noci and E. Pizzurno, 2009. Sustainability report in small enterprises: Case studies in Italian furniture companies. Business Strategy and the Environment, 18(3): 162-176.

Borga, F., A. Citterio, G. Noci and E. Pizzurno, 2009. Sustainability report in small enterprises: Case studies in Italian furniture companies. Business Strategy and the Environment, 18(3): 162-176. Available from http://0proquest.umi.com.library.ecu.edu.au/pqdweb?did=1629032871\&Fmt $=7 \&$ clientI $\underline{\mathrm{d}=7582 \& \mathrm{RQT}=309 \& \mathrm{VName}=\mathrm{PQD}}$. 
Broecker, W.S., J. Lynch-Stieglitz and E. Clark, 2001. What caused the atmosphere's $\mathrm{CO} 2$ content to rise during the last 8000 years? The Earth Sciences, 2.

Brundtlant Commission, 1987. Brundtland report. Oslo-Norway: United Nations.

Brundtlant Commission, 1987. Brundtland report. United Nations, Oslo - Norway.

Castka, P., M.A. Balzarova and C.J. Bamber, 2004. How can SMEs effectively implement the CSR agenda? A UK case study perspective. Corporate Social Responsibility and Environment Management, 11(1): 140-149.

Castka, P., M.A. Balzarova and C.J. Bamber, 2004. How can smes effectively implement the csr agenda? A uk case study perspective. Corporate Social Responsibility and Environment Management, 11(1): 140-149. Available from http://onlinelibrary.wiley.com/doi/10.1002/csr.62/pdf [Accessed 27 April 2010].

Elkington, J., 1994. Towards the sustainable corporation: Win-win-win business strategies for sustainable development. California Management Review, 36(2): 90-100.

Godfrey, P., C. Merrill and J. Hansen, 2009. The relationship between corporate social responsibility and shareholder value: An empirical test of the risk management hypothesis. Strategic Management Journal, 30(4): 425-445.

Hall, C., 2003. Impediments to international sme activity; evidence and a proposed framework for monitoring. Discussion Paper APEC SME WG Malaysia: 1-8. Available

from http://www.pecc.org/community/papers/sme/impediments to intl_sme.pdf.

Hart, S.L. and M.B. Milstein, 2003. Creating sustainable value. Academy of Management Executive, 17(2): 56-69. [Accessed 27 April 2010].

Hubbard, G., 2009. Measuring organizational performance: Beyond the triple bottom line. Business Strategy and the Environment, 18: 177-191. DOI $10.1002 /$ bse. 564 .

ICBS, 2008. Statistic official release the growth of SMEs macro indicator in 2008 (No. 28/05/Th XI, 30 Mei 2008 ed.). Jakarta - Indonesia: Indonesian Central Bureau of Statistics.

Lawrence, S.R., E. Collins, K. Pavlovich and M. Arunachalam, 2006. Sustainability practices of SMEs: The case of NZ. Business Strategy and the Environment, 15(4): 242-257.

Lawrence, S.R., E. Collins, K. Pavlovich and M. Arunachalam, 2006. Sustainability practices of smes: The case of nz. Business Strategy and the Environment, 15(4): 242-257. Available from http://0proquest.umi.com.library.ecu.edu.au/pqdweb?did=1140828761\&Fmt $=7 \&$ clientI $\underline{\mathrm{d}=7582 \& \mathrm{ROT}=309 \& \mathrm{VName}=\mathrm{PQD}}$. 
LEDIS, 2007. Does entreprenuership lead to economic growth? An unanswered question. Available from www.ledis.co.uk.

LEDIS, 2007. Does entreprenuership lead to economic growth? An unanswered question. United Kingdom.

Masurel, E., 2007. Why SMEs invest in environmental measures: Sustainability evidence from small and medium-sized printing firms. Business Strategy and the Environment, 16(3): 190-201.

Masurel, E., 2007. Why smes invest in environmental measures: Sustainability evidence from small and medium-sized printing firms. Business Strategy and the Environment, 16(3): 190-201. Available from http://0proquest.umi.com.library.ecu.edu.au/pqdweb?did=1219966481\&Fmt $=7 \&$ clientI $\underline{\mathrm{d}=7582 \& \mathrm{RQT}=309 \& \mathrm{VName}=\mathrm{PQD}}$.

MD, C.S., Y.K. MD, F.U. MD and C.S. MD, 2009. Frostbite injury of the foot from portable fire extinguisher. 15(September 2009). Available from http://dermatology-s10.cdlib.org.

Rammer, C., D. Czarnitzki and A. Spielkamp, 2009. Innovation success of non-r\&dperformers: Substituting technology by management in smes. Small Business Economics, 33(1): 35-58. Available from http://0proquest.umi.com.library.ecu.edu.au/pqdweb?did=1740505141\&Fmt=7\&clientI $\underline{\mathrm{d}=7582 \& \mathrm{RQT}=309 \& \mathrm{VName}=\mathrm{PQD}}$.

Rao, P., A. Singh, O. La O'Castillo, P. Intal, Jr. and A. Sajid, 2009. A metric for corporate environmental indicators ... For small and medium enterprises in the philippines. Business Strategy and the Environment, 18(1): 14-31. Available from http://0proquest.umi.com.library.ecu.edu.au/pqdweb?did $=1616063121 \& \mathrm{Fmt}=7 \&$ clientI $\underline{\mathrm{d}=7582 \& \mathrm{RQT}=309 \& \mathrm{VName}=\mathrm{PQD}}$.

Rao, P., A. Singh, O. La O'Castillo, P.J. Intal and A. Sajid, 2009. A metric for corporate environmental indicators ... For small and medium enterprises in the philippines. Business Strategy and the Environment, 18(1): 14-31.

Savitz, A.W. and K. Weber, 2006. How today's best-run companies are achieving economic, social, and environment success-and how you can too.

Savitz, A.W. and K. Weber, 2006. How today's best-run companies are achieving economic, social, and environment success-and how you can too. Jossey-Bass A Wiley Imprint, San Fransisco, USA.

Schipper, J., J.S. Chanson, F. Chiozza, N.A. Cox, M. Hoffmann, V. Katariya, J. Lamoreux and A.S.L. Rodrigues, 2008. The status of the world's land and marine mammals: Diversity, threat, and knowledge. Science, 322: 225-230. Available from http://www.sciencemag.org/content/322/5899/225.full.pdf [Accessed 20 Nov 2011]. 
Schipper, J., J.S. Chanson, F. Chiozza, N.A. Cox, M. Hoffmann, V. Katariya and A.S.L. Rodrigues, 2008. The status of the world's land and marine mammals: Diversity, threat, and knowledge. Science, 322: 225-230.

Scholtens, B., 2006. Finance as a driver of corporate social responsibility. Journal of Business Ethics, 68(1): 19-33.

Tang, F., 2009. Benefits of corporate social responsibility to SMEs. Paper presented at the westlake SMEs Conference 2009, Westlake - QLD.

The World Conservation Union and Species Survival Commission, 2004. Species extinction. Available from http://iucn.org.

The World Conservation Union and Species Survival Commission, 2004. Species extinction. The World Conservation Union and Species Survival Commission.

Werbach, A., 2009. Strategy for sustainability. Massachusetts - USA: Harvard Business Press.

Will, M., 2008. Talking about the future within an SME? Management of Environmental Quality, 19(2): 234-242. 